\title{
THE EFFECT OF PROGRESSIVE MUSCLE RELAXATION AND SLOW DEEP BREATHING COMBINATIONS ON SLEEP QUALITY OF PREGNANT WOMEN
}

\author{
Mufidah Sheena Andani Prastini ${ }^{1}$, Lilik Herawati ${ }^{2}$, \\ Endyka Erye Frety ${ }^{3}$, Aditiawarman ${ }^{4}$ \\ Universitas Airlangga ${ }^{1,2,3,4}$ \\ sheenandani@gmail.com
}

\begin{abstract}
Several studies suggest that poor sleep quality has an impact on both the mother and the fetus. Providing relaxation exercises in the form of progressive muscle relaxation and slow deep breathing can be a non-pharmacological effort to improve sleep quality in pregnant women. This study aims to analyze the effect of a combination of progressive muscle relaxation and slow deep breathing in pregnant women of third trimester. This research method is pre-experimental designs with a pretest-posttest control group design. The number of samples was 24 pregnant women trimester III with the sampling technique using consecutive sampling. The independent variable is the provision of progressive muscle relaxation and slow deep breathing exercises which are carried out for 3 times on a week over a period of 3 weeks. The dependent variable is sleep quality which is measured using the Pittsburgh Sleep Quality Index questionnaire. Data analysis used the Wilcoxon signed rank test. The results showed a decrease in the mean value in the direction of improved sleep quality by a difference of 4.5 in the experimental group. Whereas in the control group there was an increase in the value which led to a deteriorating sleep quality by a difference of 1.42. The test results showed a difference in the pretest and posttest of the two groups $p$ $=0.000(p<0.05)$. These data indicate that there is an effect of a combination of progressive muscle relaxation and slow deep breathing on the sleep quality pregnant women of third trimester.
\end{abstract}

Keywords: Sleep Quality, Progressive Muscle Relaxation, Slow Deep Breathing, Exercise In Pregnancy, Relaxation

Accepted: $16^{\text {th }}$ of January 2022

Correspondence author: Mufidah Sheena Andani Prastini, Universitas Airlangga. E-Mail: sheenandani@gmail.com

DOI http://dx.doi.org/10.31851/hon.v5i1.6919

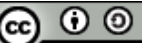

Jurnal Halaman Olahraga Nusantara licensed under a Creative Commons Attribution-ShareAlike 4.0 International License

\section{INTRODUCTION}

Sport is one element that is very influential and has been become a necessity in human life. In other respects sports too become the attitude and character of a human being, because in it there are various activities related to human behavior 
(Hilda Oktriyeni, 2019). Sport is a human way to maintain physical health. Starting from running, swimming, jumping, and other sports activities. Exercising is one way that urban communities can do to maintain body health (Okilanda, 2018) and restore freshness of mind. Sport is also a series of regular and planned physical movements that are carried out consciously to be able to improve their functional abilities (Setiawan, Ipang and Triyanto, 2014). Exercise during pregnancy has many benefits and is a caring attitude towards the condition of the body in order to stay healthy until the time of delivery. However, there are some obstacles associated with recommended exercise during pregnancy. Inhibiting factors include some people do not understand and do not have an awareness of the important benefits of doing sports. In addition, some people spend time at work then experience fatigue and no longer have time to do sports activities (Indrawan and Riyoko, 2020). In this case, pregnant women are given other alternatives in the form of exercises that can make the body more relaxed and overcome some complaints.

Women who are pregnant will experience changes both physically and psychologically. One of the changes that appear is discomfort in the form of dizziness, nausea, vomiting, difficulty breathing, heartburn, frequent urination, vaginal discharge, striae, lower back pain, leg cramps and difficulty sleeping. Based on research conducted by Abbott, Attarian and Zee (2014), 52-61\% of pregnant women experience sleep disorders in the form of insomnia. This sleep disorder usually appears in the late period of pregnancy (Román-Gálvez et al., 2018). Poor sleep quality can affect a woman's ability to cope with pain during childbirth. According to Naghi et al (2011), it can also increase the risk of longer labor, the incidence of cesarean delivery and spontaneous preterm birth.

Various efforts have been made to help pregnant women overcome complaints of difficulty sleeping. Efforts have been made ranging from pharmacological therapy to non-pharmacological therapy. Pharmacological therapy in question such as benzodiazepines and benzodiazapine receptor agonists. However, this therapy is often associated with adverse effects on the neonate. Non- 
pharmacological therapies used include acupuncture, massage therapy to relaxation exercises to meditation such as yoga. This method is given in the hope that the sleep quality of pregnant women will increase (Reichner, 2015). Relaxation exercise is one of the non-pharmacological efforts that can be done. Giving relaxation exercises in question can be in the form of progressive muscle relaxation, guided imagery, meditation and slow deep breathing. Technique Progressive muscle relaxation, which is a procedure to get relaxation in the muscles by applying tension and stopping the tension in order to feel the relaxed sensation (Syarif and Putra, 2014). Meanwhile, slow deep breathing is a deep and slowexercise that provides a relaxing effect because it works through the autonomic nervous system (Sepdianto, Nurachmah and Gayatri, 2010).

Based on the results of research conducted by Setyaningrum, Permana and Yuniarti (2018), proving that exercises are progressive muscle relaxation and slow deep breathing effective for improving sleep quality and reducing stress levels in hypertensive patients. Exercises such as Progressive muscle relaxation usually given to patients with hypertension, cancer, complaints of anxiety and depression up to post surgery. However, this combination of relaxation exercises is rarely used as an option to overcome sleep complaints in pregnant women. The purpose of this study was to analyze the effect of the combination of progressive muscle relaxation and slow deep breathing on the sleep quality of pregnant women in the third trimester. The hypothesis of this study is that there is an effect of the combination of progressive muscle relaxation and slow deep breathing on the sleep quality of third trimester pregnant women.

\section{METHOD}

This research method is a pre-experimental design with a pretest-posttest control group design. The population in this study were third trimester pregnant women in Mekarmanik Village and Sindanglaya Village. The number of samples as many as 24 third trimester pregnant women with a sampling technique using consecutive sampling. The independent variable was the provision of progressive 


\section{OLAHRAGA}

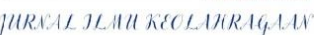

Jendral A. Yani Street Lorong Gotong Royong 9/10 U1 Palembang South Sumatera

email jurnal: jurnalhon@univpgri-palembang.ac.id situs web: http://www.univpgri-palembang.ac.id
Accredited

SINTA 3

muscle relaxation and slow deep breathing exercises which were performed $3 x /$ week for a period of 3 weeks. The dependent variable is sleep quality which is measured using the Pittsburgh Sleep Quality Index (PSQI) questionnaire. Sleep quality was measured twice before and 3 weeks after the experimental group performed relaxation exercises. The following is the operational definition of the research variables.

Table 1. Operational definitions of variables research

\begin{tabular}{|c|c|c|c|c|c|}
\hline variables & $\begin{array}{c}\text { Operational } \\
\text { definitions }\end{array}$ & $\begin{array}{l}\text { Measuring } \\
\text { instruments }\end{array}$ & Measuring & results & Scale \\
\hline $\begin{array}{l}1 . \quad \text { sleep } \\
\text { quality }\end{array}$ & $\begin{array}{l}\text { assessment } \\
\text { of how } \\
\text { deep an } \\
\text { individual } \\
\text { sleeps is } \\
\text { seen from } \\
\text { several } \\
\text { indicators } \\
\text { that will } \\
\text { affect } \\
\text { physical } \\
\text { condition } \\
\text { upon } \\
\text { awakening }\end{array}$ & $\begin{array}{l}\text { 1. Pittsburgh } \\
\text { Sleep } \\
\text { Quality } \\
\text { Index(PSQI) } \\
\text { questionnaire } \\
\text { 2. structured } \\
\text { interview }\end{array}$ & $\begin{array}{l}\text { 1.check list of } \\
\text { PSQI } \\
\text { questionnaires } \\
\text { 2. Interview } \\
\text { results } \\
\text { received by } \\
\text { respondents } \\
\text { after being } \\
\text { given } \\
\text { treatment }\end{array}$ & $\begin{array}{l}\text {-changes in the quality } \\
\text { of sleep of pregnant } \\
\text { women entering the } \\
\text { third trimester of } \\
\text { gestational age 28-35 } \\
\text { weeks in the form of } \\
\text { increasing or } \\
\text { decreasing sleep } \\
\text { quality scores. } \\
\text { Jood sleep quality : } \leq 5 \\
\text { Bad sleep quality : }>5 \\
\text {-the effect of } \\
\text { progressive muscle } \\
\text { relaxation and slow } \\
\text { deep breathing }\end{array}$ & Ratio \\
\hline $\begin{array}{l}2 . \\
\text { Progressive } \\
\text { muscle } \\
\text { relaxation }\end{array}$ & $\begin{array}{l}\text { An exercise } \\
\text { method that } \\
\text { involves } \\
\text { tensing the } \\
\text { muscles } \\
\text { throughout } \\
\text { the body } \\
\text { before } \\
\text { relaxing } \\
\text { them. }\end{array}$ & $\begin{array}{l}\text { Exercise of } \\
\text { Progressive } \\
\text { muscle } \\
\text { relaxation }\end{array}$ & $\begin{array}{l}\text { Correct } \\
\text { direction } \\
\text { according to } \\
\text { instructions }\end{array}$ & $\begin{array}{l}\text { Do the steps of PMR } \\
\text { correctly }\end{array}$ & Nominal \\
\hline $\begin{array}{l}3 . \quad \text { slow } \\
\text { deep } \\
\text { breathing }\end{array}$ & $\begin{array}{l}\text { technique } \\
\text { with a } \\
\text { breathing } \\
\text { frequency } \\
\text { of less than } \\
10 \text { times } \\
\text { per minute } \\
\text { and a long } \\
\text { inhalation } \\
\text { phase }\end{array}$ & $\begin{array}{l}\text { Exercises } \\
\text { slow deep } \\
\text { breathing }\end{array}$ & $\begin{array}{l}\text { Correct } \\
\text { direction } \\
\text { according to } \\
\text { instructions }\end{array}$ & $\begin{array}{l}\text { Do the steps slow deep } \\
\text { breathing correctly }\end{array}$ & Nominal \\
\hline
\end{tabular}


This study involved two groups, namely the control group and the experimental group. Data collection is done early(pretest) using a questionnaire to measure the quality of sleep in both groups of respondents. In the experimental group, respondents will be given exercises progressive muscle relaxation and slow deep breathing for a period of 3 weeks. Meanwhile, the control group was not given any intervention for 3 weeks. After 3 weeks, respondents will be asked to fill out the same questionnaire at the time of the pretest to measure their sleep quality. Data processing is done by editing, coding, entry, cleaning, and tabulating data. The collected and processed data were then analyzed using the Wilcoxon signed rank test and the Mann Whitney test with the help of the SPSS computer program.

\section{RESULTS}

1. The results of the analysis of the general characteristics of research respondents

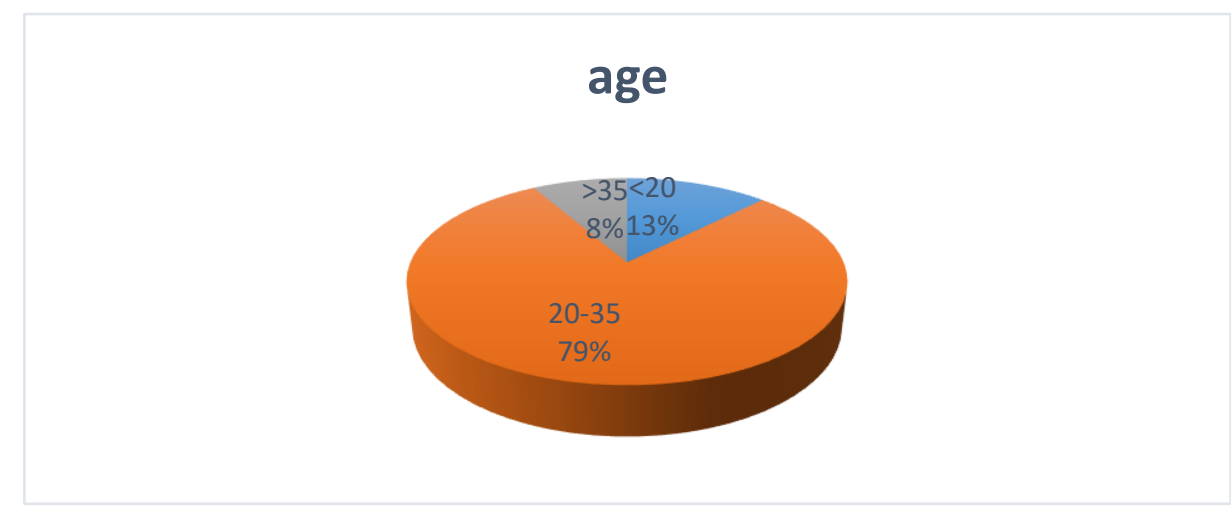

Figure 1. Characteristics by age

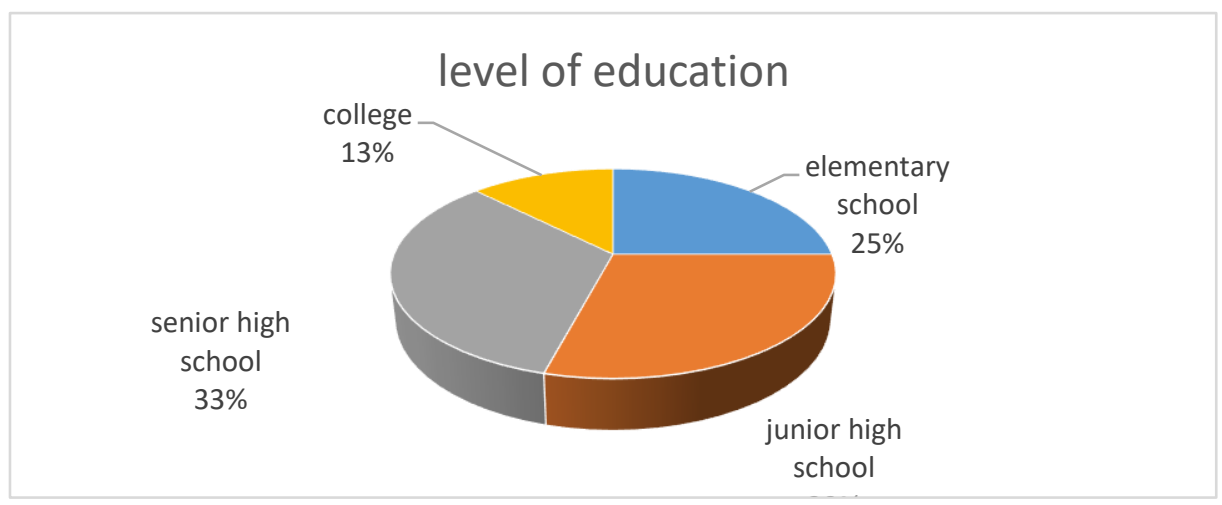




\section{OLAHRAGA}

Jendral A. Yani Street Lorong Gotong Royong 9/10 Ulu

Figure 2. Characteristics by level of education

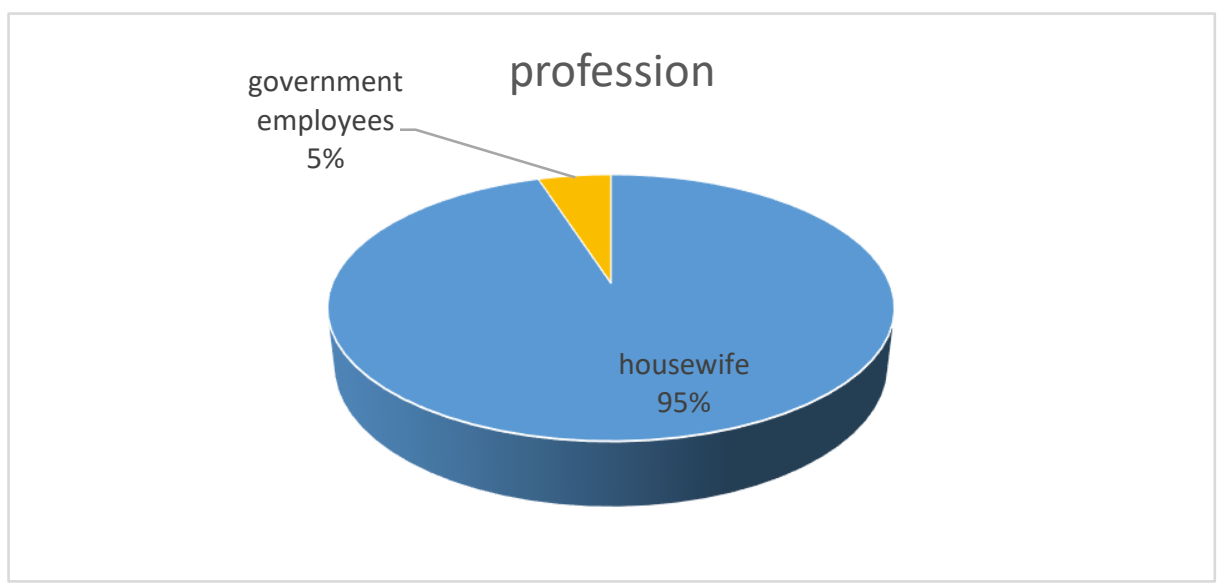

Figure 3. Characteristics by profession

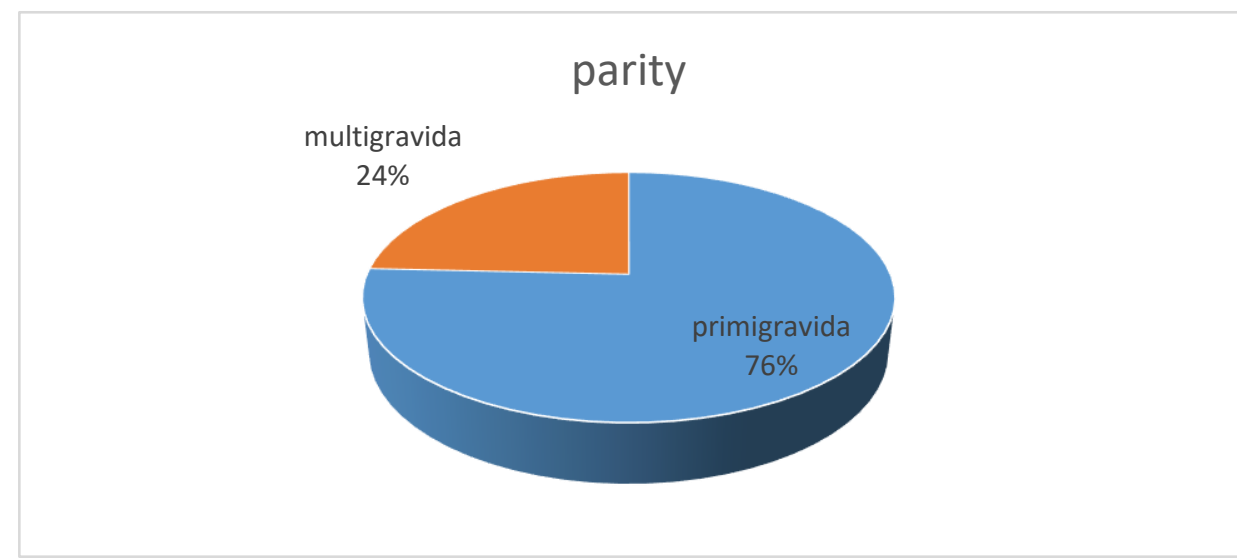

Figure 4. Characteristics by parity

Based on the table above, most (79.2\%) of respondents are in the age range of 20-35 years. The average respondent studied up to high school level as much as $33.3 \%$. Most of the activities that respondents do at home can be seen from the dominant occupation being housewives $(95.8 \%)$. Meanwhile, related to the parity of respondents who had experienced pregnancy more than once as many as $58.3 \%$ and respondents who were primiparous as many as $41.7 \%$.

2. The difference test between pre-test and post-test.

Based on data processing using the SPSS program, the results are shown in the following table. 
Table 2. The results of the difference in sleep quality pretest and posttest between the control and experimental

\begin{tabular}{cccc}
\hline Groups & $\begin{array}{c}\text { Pre } \\
(\text { mean } \pm \text { SD) }\end{array}$ & $\begin{array}{c}\text { Post } \\
(\text { mean } \pm \text { SD })\end{array}$ & difference \\
\hline Control & $6,75 \pm 2,734$ & $8,17 \pm 2,657$ & $-2,92$ \\
Experimental & $9,67 \pm 2,146$ & $5,17 \pm 1,267$ & 3 \\
p value & 0,005 & 0,003 & 0,000 \\
\hline
\end{tabular}

From the results of the analysis obtained the mean and standard deviation of each group, both results pretest and posttest. The $\mathrm{p}$ value of the difference between the pretest and posttest of the two groups shows the result of 0.000 . This result is less than the significant value of 0.05 so it means that there is a significant difference in the difference between the scores pretest and posttest. Based on the results of the Mann Whitney U Test, the data pretest has a $p$ value of 0.005 or a $p$ value $<0.05$. This indicates that there are differences in the results of the pretest both in the control and experimental groups. At the beginning of the treatment, the condition of the subject was not homogeneous. This condition occurs because in the initial data collection, the same criteria were determined only for gestational age, namely the third trimester. However, it did not adjust the respondent's specific criteria such as age, education level, income to the number of parity.

The experimental group had a mean value pretest greater of 9.67 and the control group had a pretest with an average value of 6.75 . From the results of the scores pretest, the majority of respondents in both the control and experimental groups had poor sleep quality. The post test data has a significance value of 0.003 or a $\mathrm{p}$ value $<0.05$. This shows that there are differences in results posttest in both the control group and the experimental group. After observing for 3 weeks, the value posttest showed an inversely proportional result. In the control group that was not given any treatment, the score increased which indicated that the quality of sleep was getting worse from the initial conditions with the mean value posttest of 8.17. Meanwhile, the experimental group that was given the treatment experienced a decrease in value which indicated an improvement in sleep quality with a mean value of 5.17 . 
3. Different test between groups.

Table 3. The results of the different test of sleep quality between data pretestposttest and in each control and experimental group

\begin{tabular}{ccccc}
\hline No. & Group & $\begin{array}{c}\text { Pre } \\
(\text { mean } \pm \text { SD })\end{array}$ & $\begin{array}{c}\text { Post } \\
(\text { mean } \pm \text { SD) }\end{array}$ & P value \\
\hline 1. & Control & $6,75 \pm 2,734$ & $8,17 \pm 2,657$ & 0,024 \\
2. & Experimental & $9,67 \pm 2,146$ & $5,17 \pm 1,267$ & 0,002 \\
\hline
\end{tabular}

Based on the above table, the group the control results obtained $p<0.05$

which means there is a significant difference between the results of the pretest and posttest. There was an increase in the mean value from $6.75 \pm 2.734$ in the pretest to $8.17 \pm 2.657$ at the posttest. An increase in this value indicates a change that leads to worsening sleep quality. In the experimental group, the results of $p<0.05$, which means that there is a significant difference between the results of the pretest and posttest. There was a decrease in the mean value from $9.67 \pm 2.146$ in the pretest to $5.17 \pm 1.267$ at the posttest. This decreasing value indicates a change that leads to better sleep quality than the initial condition before receiving treatment. So it can be concluded that there is an effect of giving a combination of progressive muscle relaxation and slow deep breathing on the sleep quality of pregnant women in the third trimester.

\section{DISCUSSION}

The results of the analysis show that the provision of relaxation exercises in the form of progressive muscle relaxation and slow deep breathing has an effect on improving the sleep quality of pregnant women in the third trimester. There were significant changes before and after the relaxation exercise was given. In the control group, there were differences in the results of the pretest and posttest with $p<0.05$. The sleep quality of pregnant women in the third trimester did not change and even tended to increase in value leading to poor sleep quality. This can be due to the absence of intervention to overcome complaints of difficulty sleeping which usually occurs in third trimester pregnant women.

As many as 66-94\% of pregnant women experience sleep disturbances. This complaint will continue to increase with increasing gestational age (Facco et al, 
2010). Normally pregnant women have about 7-9 hours of sleep at night. However, due to the emergence of complaints this sleep time could be reduced. Causes of difficulty sleeping in third trimester pregnant women include heartburn, disturbances from active fetal movement, leg cramps and shortness of breath. This sleep disorder will generally worsen near delivery because of the secretion of oxytocin which is a wake-upon hormone (Pires et al., 2010).

In the experimental group, the $\mathrm{p}$ value was 0.002 , which means that there are differences in the results of the pretest and posttest. The groups that were given this treatment or intervention showed different results. The sleep quality of pregnant women in the third trimester tends to decrease and leads to improved sleep quality. These results are in line with research conducted by Cicek and Basar (2017), which found that deep breathing techniques are an effective method for reducing anxiety and influencing labor duration. Kortiler and Chen in 2011 said that this technique is one way for pregnant women to learn to relax so that it can reduce stress. Progressive muscle relaxation can cause a decrease in heart rate, respiratory rate and blood pressure. This relaxation has also been shown to reduce symptoms of low back pain and improve quality of life during pregnancy (Akmeşe and Oran, 2014).

The combination of progressive muscle relaxation and slow deep breathing is very effective in reducing stress and anxiety after a stressor occurs. This technique can be taught to people who are trying to control anxiety or manage stress (Erford, 2016). This relaxation exercise can help pregnant women get more comfortable sleep and better quality sleep by helping reduce muscle tension. In this study it was also found that pregnant women in the relaxation exercise group experienced more comfortable sleep as a result of decreased muscle tension, stress, and pain perception with the help of relaxation exercises (Özkan and Rathfisch, 2018). Progressive muscle relaxation and slow deep breathing have the same goal, namely trying to relax the body which can have an impact on the sleeping habits of pregnant women. However, each exercise has its own mechanism to improve sleep quality. Progressive muscle relaxation focuses more on the muscles, while slow 
deep breathing helps bring about relaxation through deep breathing which also reduces muscle tension in the body. Therefore, the combination of these two relaxation exercises can be an alternative in overcoming complaints of insomnia in pregnant women non-pharmacologically because it can reduce muscle tension and anxiety.

\section{CONCLUSION}

1. There is a difference in sleep quality before and after being given a combination of progressive muscle relaxation and slow deep breathing exercises.

2. The combination group of progressive muscle relaxation and slow deep breathing has an influence in improving the sleep quality of pregnant women in the third trimester.

\section{SUGGESTION}

This relaxation exercise can be an alternative solution in helping reduce complaints of difficulty sleeping for pregnant women in third trimester with nonpharmacologically method. This research is expected to add insight so that the information received can be shared to help others. Relaxation exercises are better given in early pregnancy to prepare the body of pregnant women to deal with complaints that will arise in the final trimester. In addition, the application of relaxation exercises that are carried out at the earliest possible time can have a more pronounced impact because the body needs a process for adaptation in dealing with these complaints naturally.

\section{REFERENCES}

Abbott, S. M., Attarian, H. and Zee, P. C. (2014) 'Sleep disorders in perinatal women', Best Practice and Research: Clinical Obstetrics and Gynaecology. Elsevier Ltd, 28(1), pp. 159-168. doi: 10.1016/j.bpobgyn.2013.09.003.

Akmeşe, Z. B. and Oran, N. T. (2014) 'Effects of Progressive Muscle Relaxation Exercises Accompanied by Music on Low Back Pain and Quality of Life During Pregnancy', Journal of Midwifery and Women's Health, 59(5), pp. 503-509. doi: 10.1111/jmwh.12176.

Cicek, S., \& Basar, F. (2017). The Effects of Breathing Techniques Training on The Duration of Labor and Anxiety Levels of Pregnant Women. Complement Ther Clin Pract 29:213-219. Available from : https://www.ncbi.nlm.nih.gov/pubmed/2912 2264. 
Jendral A. Yani Street Lorong Gotong Royong 9/10 U1 Palembang South Sumatera

email jurnal: jurnalhon@univpgri-palembang.ac.id situs web: http://www.univpgri-palembang.ac.id

\section{Accredited}

SINTA 3

Erford, B. T. (2016). Techniques Every Counselor Should Know (2nd ed.) Yogyakarta: Pustaka Pelajar.

Facco FL, Kramer J, et al. (2010). Sleep disturbances in pregnancy. Obstet Gynecol 2010; 115: 77-83.

Hilda Oktriyeni (2019) 'Kecerdasan Gerak Dalam Pendidikan Jasmani', Halaman Olahraga Nusantara, 2(April), pp. 33-35.

Indrawan, Y. and Riyoko, E. (2020) 'Kebijakan Dispora Kota Palembang Dalam Megembangkan Minat Masyarakat Untuk Berolahraga', Halaman Olahraga Nusantara (Jurnal Ilmu Keolahragaan), 3(2), p. 157. doi: 10.31851/hon.v3i2.4449.

Kottler, J. A., \& Chen, D. D. Stress Management and Prevention (2nd ed.). New York: Routledge; 2011.

Naghi, I. et al. (2011) 'Sleep disturbance in late pregnancy and type and duration of labour', Journal of Obstetrics and Gynaecology, 31(6), pp. 489-491. doi: 10.3109/01443615.2011.579196.

Okilanda, A. (2018) 'Revitalisasi Masyarakat Urban/Perkotaan Melalui Olahraga Petanque', Halaman Olahraga Nusantara (Jurnal Ilmu Keolahragaan), 1(1).

Özkan, S. A. and Rathfisch, G. (2018) 'The effect of relaxation exercises on sleep quality in pregnant women in the third trimester: A randomized controlled trial', Complementary Therapies in Clinical Practice, 32(May), pp. 79-84. doi: 10.1016/j.ctcp.2018.05.008.

Pires, G. N. et al. (2010) 'Sleep impairment during pregnancy: Possible implications on mother-infant relationship', Medical Hypotheses. Elsevier Ltd, 75(6), pp. 578-582. doi: 10.1016/j.mehy.2010.07.036.

Reichner, C. A. (2015) 'Insomnia and sleep deficiency in pregnancy', Obstetric Medicine, 8(4), pp. 168-171. doi: 10.1177/1753495X15600572.

Román-Gálvez, R. M. et al. (2018) 'Factors associated with insomnia in pregnancy: A prospective Cohort Study', European Journal of Obstetrics and Gynecology and Reproductive Biology. Elsevier Ireland Ltd, 221, pp. 70-75. doi: 10.1016/j.ejogrb.2017.12.007.

Sepdianto, T. C., Nurachmah, E. and Gayatri, D. (2010) 'Penurunan Tekanan Darah dan Kecemasan Melalui Latihan Slow Deep Breathing Pada Pasien Hipertensi Primer', Jurnal Keperawatan Indonesia, 13(1), pp. 37-41. doi: 10.7454/jki.v13i1.229.

Setiawan, Ipang and Triyanto, H. (2014) 'Pengembangan Permainan Tradisional Gobak Sodor Bola Dalam Pembelajaran Penjas Pada Siswa SD’, media ilmu keolahragaan indonesia, 4(1). 
Setyaningrum, N., Permana, I. and Yuniarti, F. A. (2018) 'Progressive Muscle Relaxation dan Slow Deep Breathing pada Penderita Hipertensi', Jurnal Persatuan Perawat Nasional Indonesia (JPPNI), 2(1), p. 33. doi: 10.32419/jppni.v2i1.81.

Syarif, H. and Putra, A. (2014) 'Pengaruh Progressive Muscle Relaxation Terhadap Penurunan Kecemasan Pada Pasien Kanker Yang Menjalani Kemoterapi; a Randomized Clinical Trial', Idea Nursing Journal, 5(2), pp. 1-5. 